\title{
Cutaneous changes in rats induced by chronic skin exposure to ultraviolet radiation and organophosphate pesticide ${ }^{1}$
}

\author{
Tania Rita Moreno de Oliveira Fernandes ${ }^{\mathrm{I}}$, Itamar Santos ${ }^{\mathrm{I}}$, Juliana Pedrosa Korinsfky ${ }^{\mathrm{II}}$, Benedyto Sávio Lima e Silva \\ Luis Otávio Carvalho ${ }^{\mathrm{III}}$, Hélio Plapler ${ }^{\mathrm{IV}}$
}

\begin{abstract}
IAssociate Professor, Department of Medicine, Federal University of Sao Francisco Valley (UNIVASF), Petrolina-PE, Brazil. Acquisition and interpretation of data.

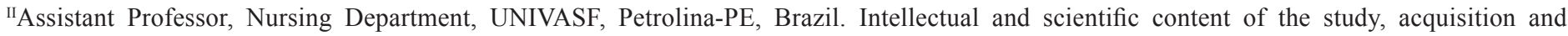
interpretation of data.

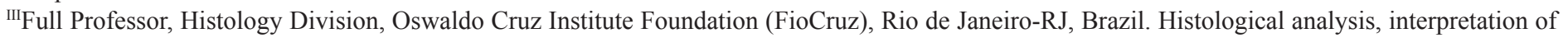
data, intellectual content of the study.

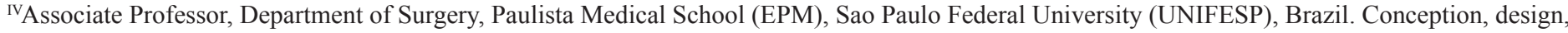
intellectual and scientific content of the study, critical revision.
\end{abstract}

\begin{abstract}
PURPOSE: To study the possible potentiation of the carcinogenic effects of ultraviolet radiation associated with an organophosphate pesticide.

METHODS: Forty Wistar rats were assigned into four groups ( $\mathrm{n}=10$ each) randomized according to the procedures: group A received only UVR-B radiation; group B, UVR-B for eight weeks followed by a seven week period of pesticide exposure; group C, UVR-B + pesticide concomitantly: group D, only pesticide application. At the end of the fifth, tenth and fifteenth weeks the animals were photographed. Skin biopsy and histopathological study with Hematoxylin-Eosin were done on the fifteenth week. Statistical analysis with Fisher's and Sign (unilateral) tests, 5\% value for significance.

RESULTS: Macroscopic lesions in the group A evolved from the erythema to erythema + desquamation. The groups B and C, with the association of two carcinogens, and group D presented evolution to keratosis, with higher incidence in group D. The histology showed a significant increase in the severity of injuries when the UVR-B and the pesticide were applied simultaneously, leading to cellular atypia. CONCLUSIONS: Concurrent association of UVR-B to organophosphate pesticide produced more severe lesions microscopically, although this has not been so apparent macroscopically. In daily practice the clinical evaluation should be complemented with laboratory evaluation.
\end{abstract}

Key words: Epidermis. Solar Radiation. Skin Neoplasms. Organophosphates. Rats. 


\section{Introduction}

Skin cancer (SC) is first place in prevalence in the world. According to the National Institute of Cancer (INCA), 134.00 of non-melanoma SC new cases were expected in Brazil in 2010, being the most frequent neoplasia in the Brazilian population for both genders, representing approximately $25 \%$ of the total number of new cases of cancer ${ }^{1}$.

The American Cancer Society estimated that, in 2007, more than one million cases of non-melanoma skin cancer (NMSC) - basal cells carcinoma (BCC) and spinocellular carcinoma (SCC) - and about 60.000 cases of melanoma (CM) would be associated to ultraviolet radiation (UVR) ${ }^{1}$.

Carcinogenesis begins when the DNA of a cell is damaged by the exposure to mutagenic endogenous and/or exogenous substances during cell division, resulting in mutations, chromosomal translocations, deletions, inversions or gene amplification. The promoting stage of the tumor is characterized by successive clonal expansion of tumor cells, and the genetic alterations and environment factors, such as the exposure to ultraviolet radiation (UVR) and to cancerous substances, are responsible for the majority of cancer $\operatorname{cases}^{2-6}$. Pesticides induce cancer through various mechanisms, such as gentoxicity and tumor promotion involving hormonal, immunological mediators and the production of oxidant molecules peroxide ${ }^{8}$.Its absorption through the skin varies according to room temperature (bigger in high temperatures), air humidity, contact time with the skin and carcinogenic potential. Studies about toxicity of pesticides use a $50 \%$ dermic lethal dose (LD-50 dermic) ${ }^{9}$.

Petrolina and Juazeiro are neighbor cities, with the biggest urban population in the Brazilian semi-arid climate region, approximately 530.747 people $^{10}$, corresponding to $50 \%$ of the economically active population ${ }^{11}$. In order to make the agricultural economy possible, the pesticides are used indiscriminately. According to Bedor ${ }^{9}$, the most used pesticides in the region belong to the following groups: organophosphate s $(25 \%)$, piretodes $(9 \%)$, benzimidazole and triazole $(6 \%)$, neocotinodes $(5 \%)$.

Among the organophosphates, Folisuper $^{\circledR}$ (parationametílica): O,O- dimethyl O- 4- nitrophenylphosphorothioate (molecular formula C8H10NO5PS) is the most used one, classified as extremely toxic. It has been considered inmany pre carcinogenic studies as being very dangerous to the environment ${ }^{9}$. Organophosphates are highly soluble in lipids and they can be absorbed by the skin, either by ingestion or inhalation.

Solar radiation in known as a carcinogenic factor and pesticides are co-carcinogenic to the human body and has the skin as one of its main ways of absorption. This study aims at evaluate a causal link between this association and SC.

\section{Methods}

This project was approved by the Animal Experimentation Ethic Committee of São Paulo Federal University (protocol number 1146/10) and Scientific Research Ethic Committee at the Sao Francisco Valley University (protocol no 12081048).

This is an animal model aligned to a follow-up study, using forty 3-month-old, male Wistar rats (Rattus norvegicus albinus), with average weight of $250 \pm 30 \mathrm{~g}$ proceeding from the laboratory animal center.

All animals were shaved leaving a bald dorsal area measuring $3 \times 3 \mathrm{~cm}$ every seven days, with an electrical shaver and then were randomly assigned into four groups, called A, B, C and D. The observation time was 15 weeks (from 05/07/2010 to 17/10/2010). This time interval was determined by the arithmetical average of observation time used by Fisher et al. ${ }^{11}$, Mitchell et al. ${ }^{12}$, Kligman et al. ${ }^{13}$, Schwartz ${ }^{14,15}$ and Wulff et al. ${ }^{16}$.

Group A ( $n=10)$ had UVR-B applied to the animals skin. Group B $(n=10)$ had its animals exposed to UVR-B for eight weeks, then associated to a seven week period when a layer of pesticide was also applied. In group $C(n=10)$, the skin of the animals was exposed to UVR-B followed by a layer of pesticide alone. In group D $(n=10)$, only a layer of pesticide was applied.

\section{Procedures}

\section{Pesticide application}

A solution of "Folisuper ${ }^{\mathbb{B} "}$ (C8H10NO5PS) diluted in distilled water $0,4 \mathrm{mg} / \mathrm{kg}$ (according to the product label directions) was applied topically on the shaved dorsal skin of the animals three times a week for 15 weeks through a wooden stamp with foam on its extremity.

\section{$\underline{\text { Ultraviolet radiation (UVR-B) }}$}

A UVR emitter device was used for stable wave lengths ( $\lambda$ ) of 312nm (type B) Spectroline ${ }^{\circledR}$ ENB-260 C-Dual Wavelength E series and power of $6 \mathrm{~J} / \mathrm{s}(\mathrm{W})$ and 1,7A Long wave (UVA $365 \mathrm{~nm}$ )/ Medium wave (UVB 312nm) (Espectronic Co. St. Westberry, Ny, USA), In order to use this device, a wooden rectangular box was confectioned to keep the animal immobilized while submitted to radiation, $20 \mathrm{~cm}$ away from the UVR $-\mathrm{B}$ emitter device. The animals from groups $\mathrm{A}, \mathrm{B}$ and $\mathrm{C}$ were exposed for 30 seconds three times a week ${ }^{15,16}$. Exposure time was based on the lamp 
potency and minimum time necessary to obtain twice as much the erythematous dose on the animal skin.

\section{Photograph analysis}

Pictures were taken at the end of the fifth, tenth and fifteenth weeks and analyzed blindly by an experienced dermatologist according to the following score: no lesion, physical scar, erythema, erythema with desquamation, keratosis, ulcer, crust and vegetation.

\section{Biopsy procedures and histologic analysis}

After identification, skin fragments were sent for histological analysis in a $10 \%$ formaldehyde solution, to FioCruz Laboratory in Rio de Janeiro and stained by the HemathoxylinEosin method. They were photographed, being prioritized the sites with more pathological findings (10 and 20 fold objective). A high resolution video camera (AxionCam MRC, Carl Zeiss ${ }^{\circledR}$, Jena, German) was attached to the microscope.

\section{Histological analysis}

The analysis took place at the Histotec Pathology Laboratory, located in Petrolina-PE, by a pathologist using a Nikon microscope model Elipse E 200 with binocular lenses with enlargement of $10 \mathrm{x}$ and objective with enlargement $\mathrm{x} 40 / 0.65$ attached to the video camera. To the microscopic analysis the following alterations were considered ${ }^{2,3,17}$ :

Acanthosis: thickening of the spinous layer due to the increase in the number and size of cells.
Hyperkeratosis: thickening of the horny layer of the epidermis, infundibulum or eccrine/apocrine ducts.

Epithelial dysplasia: atypical and irregular proliferative response to chronic irritation, reversible, characterized by the increase in proliferation associated to the presence of atypical cells, involving alterations in cell size, number and organization.

Cellular atypia: changes in size and shape of the cell, nucleus and nucleolus; disproportion of the nuclear and cytoplasmic presence of abnormal mitoses.

\section{Statistical analysis}

Macroscopic: a descriptive analysis of the variables has been carried out using the exact test performed by Fisher and the Signal test (unilateral).

Microscopic: the distributions of the frequency of variables were compared in the four groups by the exact test of Fisher. In all comparisons the probabilities lower than 0.05 were taken into consideration.

\section{Results}

The results of this study are presented in the following tables and pictures.

\section{Macroscopic analysis}

Tables 1 to 3 display the distribution of the skin lesions and Figures 1 to 4 exemplify them.

TABLE 1 - Perceptual distribution of the studied variables (mode) at fifth week.

\begin{tabular}{|c|c|c|c|c|c|c|}
\hline \multirow{3}{*}{ Statistic variable } & \multicolumn{4}{|c|}{ Groups } & \multirow{2}{*}{\multicolumn{2}{|c|}{$\begin{array}{c}\text { Comparison } \\
\text { between groups }\end{array}$}} \\
\hline & \multirow{2}{*}{ A } & \multirow{2}{*}{$\mathrm{B}$} & \multirow{2}{*}{$\mathrm{C}$} & \multirow{2}{*}{$\mathrm{D}$} & & \\
\hline & & & & & value - $\mathrm{p}$ & Conclusion at $5 \%$ \\
\hline \multirow[t]{2}{*}{ Number of rats } & 10 & 10 & 10 & 10 & & \\
\hline & & & & & Fisher's test & \\
\hline Frequency & & & & & 0.698 & accepted H0 \\
\hline $\mathrm{N}^{\mathrm{o}}$ lesion (n) & $10 \%(1)$ & $0 \%(0)$ & $10 \%(1)$ & $0 \%(0)$ & & \\
\hline Physical excoriation (n) & $0 \%(0)$ & $0 \%(0)$ & $10 \%(1)$ & $10 \%(1)$ & & \\
\hline Erythema (n) & $40 \%(4)$ & $30 \%(3)$ & $40 \%(4)$ & $30 \%(3)$ & & \\
\hline Erythema with Dequamation (n) & $20 \%(2)$ & $40 \%(4)$ & $10 \%(1)$ & $10 \%(1)$ & & \\
\hline Keratosis (n) & $30 \%(3)$ & $20 \%(2)$ & $30 \%(3)$ & $50 \%(5)$ & & \\
\hline $\operatorname{Ulcer}(n)$ & $0 \%(0)$ & $0 \%(0)$ & $0 \%(0)$ & $0 \%(0)$ & & \\
\hline Crust (n) & $0 \%(0)$ & $10 \%(1)$ & $0 \%(0)$ & $0 \%(0)$ & & \\
\hline Vegetation (n) & $0 \%(0)$ & $0 \%(0)$ & $0 \%(0)$ & $0 \%(0)$ & & \\
\hline Total & $100 \%(10)$ & $100 \%(10)$ & $100 \%(10)$ & $100 \%(10)$ & & \\
\hline
\end{tabular}


Fernandes TRMO et al.

TABLE 2 - Perceptual distribution of the studied variables (mode) at tenth week.

\begin{tabular}{|c|c|c|c|c|c|c|}
\hline \multirow{2}{*}{ Statistic variable } & \multicolumn{4}{|c|}{ Groups } & \multicolumn{2}{|c|}{ Comparison between groups } \\
\hline & $\mathrm{A}$ & $\mathrm{B}$ & $\mathrm{C}$ & $\mathrm{D}$ & value - $p$ & Conclusion at $5 \%$ \\
\hline Number of rats & 10 & 10 & 10 & 10 & & \\
\hline Frequency & & & & & 0.744 & accepted H0 \\
\hline $\mathrm{N}^{\mathrm{o}}$ lesion (n) & $0 \%(0)$ & $0 \%(0)$ & $0 \%(0)$ & $0 \%(0)$ & & \\
\hline Erythema / dequamation (n) & $50 \%(5)$ & $40 \%(4)$ & $20 \%(2)$ & $30 \%(3)$ & & \\
\hline Keratosis (n) & $20 \%(2)$ & $30 \%(3)$ & $50 \%(5)$ & $50 \%(5)$ & & \\
\hline Total & $100 \%(10)$ & $100 \%(10)$ & $100 \%(10)$ & $100 \%(10)$ & & \\
\hline
\end{tabular}

TABLE 3 - Perceptual distribution of the studied variables (mode) at fifteenth week.

\begin{tabular}{|c|c|c|c|c|c|c|}
\hline \multirow{2}{*}{ Statistic variable } & \multicolumn{3}{|c|}{ Groups } & \multicolumn{3}{|c|}{ Comparison between groups } \\
\hline & A & B & $\mathrm{C}$ & $\mathrm{D}$ & Value-p & Conclusion at 5\% \\
\hline \multirow[t]{2}{*}{ Number of rats } & 10 & 10 & 10 & 10 & & \\
\hline & & & & & Fisher's test & \\
\hline frequency & & & & & 0.222 & accepted $\mathrm{H} 0$ \\
\hline $\mathrm{N}^{\circ}$ lesion $(\mathrm{n})$ & $10 \%(1)$ & $0 \%(0)$ & $10 \%(1)$ & $0 \%(0)$ & & \\
\hline Physical excoriation (n) & $0 \%(0)$ & $0 \%(0)$ & $10 \%(1)$ & $0 \%(0)$ & & \\
\hline Erythema (n) & $0 \%(0)$ & $20 \%(2)$ & $20 \%(2)$ & $10 \%(1)$ & & \\
\hline Erythema / dequamation (n) & $60 \%(6)$ & $20 \%(2)$ & $20 \%(2)$ & $10 \%(1)$ & & \\
\hline Keratosis (n) & $30 \%(3)$ & $60 \%(6)$ & $40 \%(4)$ & $80 \%(8)$ & & \\
\hline Ulcer (n) & $0 \%(0)$ & $0 \%(0)$ & $0 \%(0)$ & $0 \%(0)$ & & \\
\hline Crust (n) & $0 \%(0)$ & $0 \%(0)$ & $0 \%(0)$ & $0 \%(0)$ & & \\
\hline Vegetation (n) & $0 \%(0)$ & $0 \%(0)$ & $0 \%(0)$ & $0 \%(0)$ & & \\
\hline Total & $100 \%(10)$ & $100 \%(10)$ & $100 \%(10)$ & $100 \%(10)$ & & \\
\hline
\end{tabular}

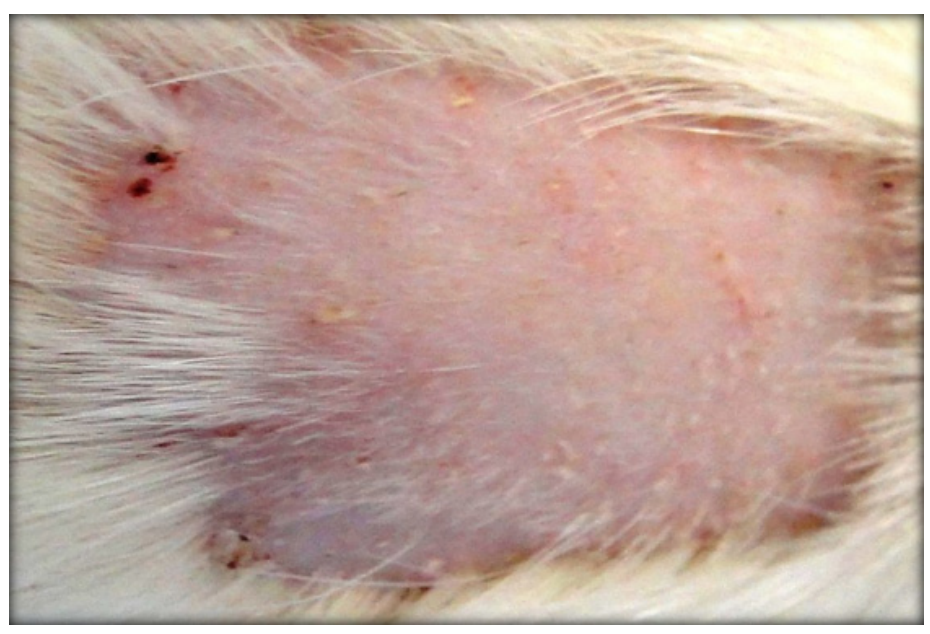

FIGURE 1 - Group A: keratosis and erythema.

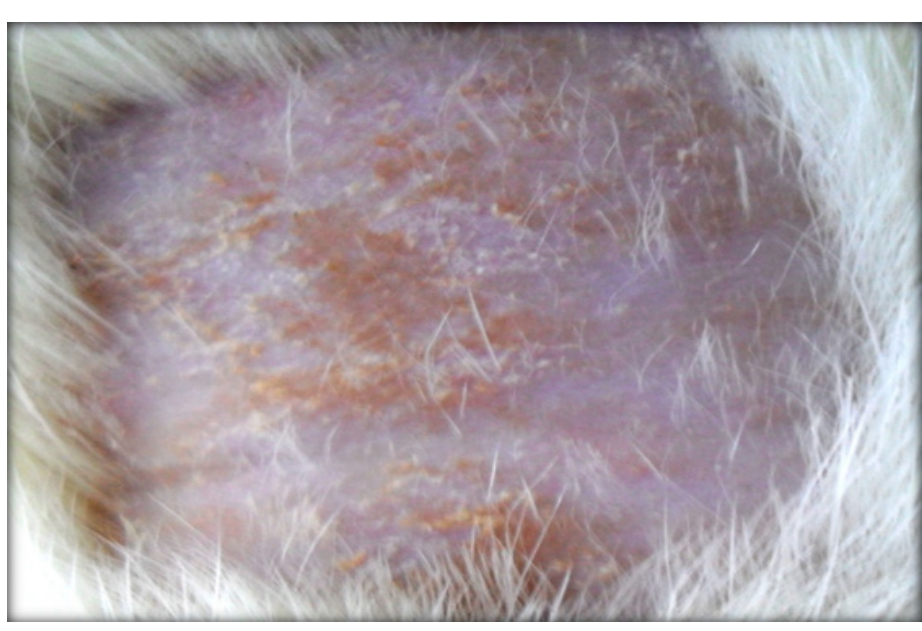

FIGURE 2 - Group B: advanced keratosis, erythema and scars. 


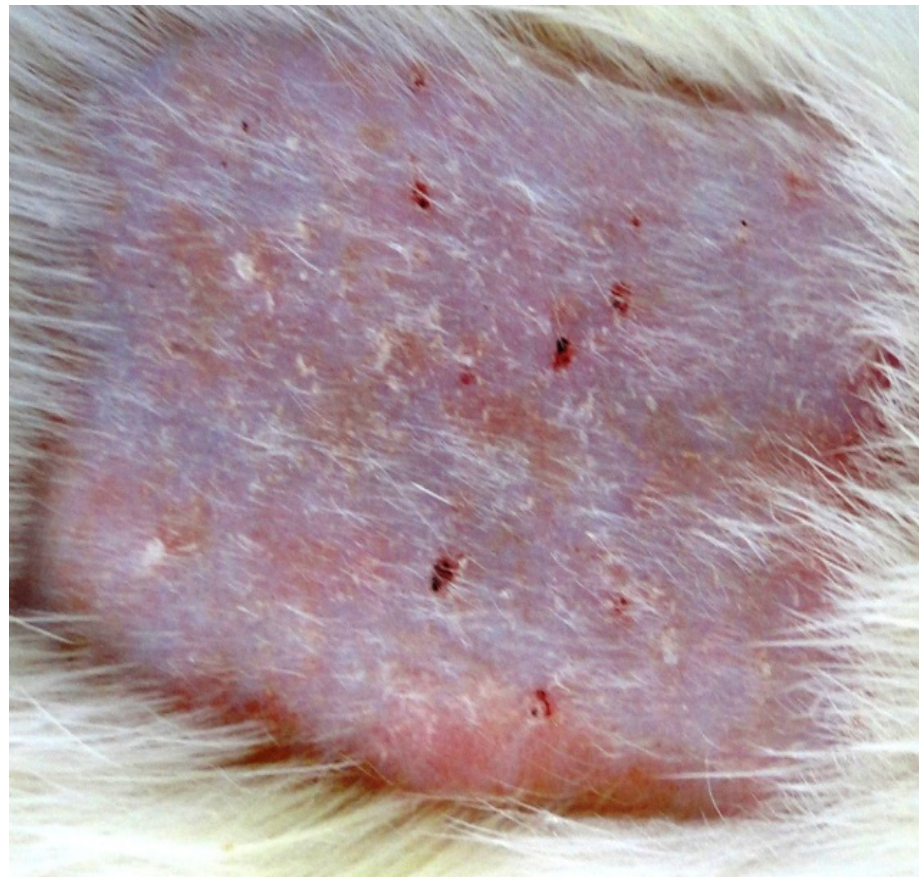

FIGURE 3 - Group C: keratosis, erythema and scars.

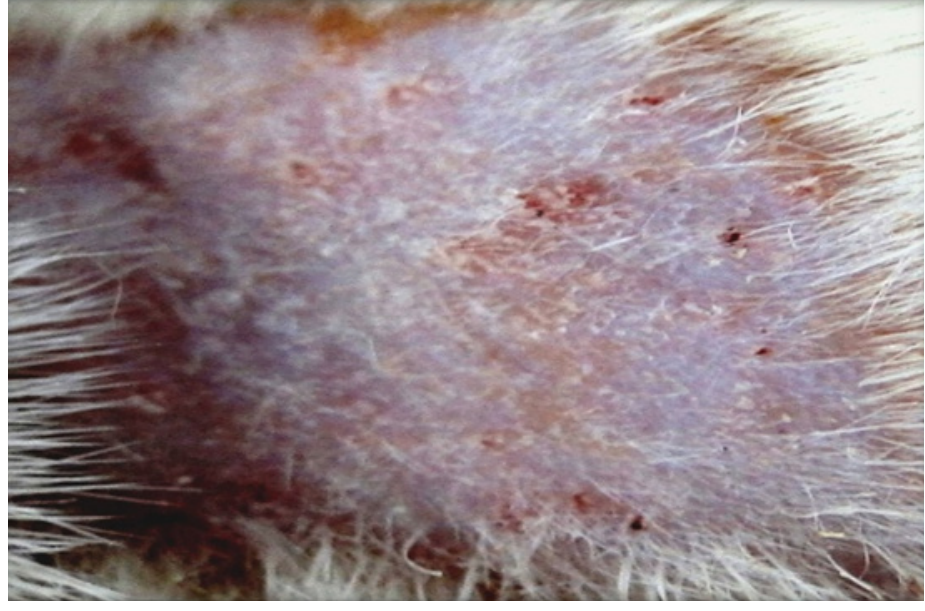

FIGURE 4 - Group D: intense keratosis, erythema.

\section{Histological findings}

Among the alterations found as representative for the purpose of this study, we chose the following variables: acanthosis, hyperkeratosis, dysplasia and cell atypia (Table 4).

Figures 5 to 8 display the histological findings listed in Table 4.

TABLE 4 - Percentage distribution (frequency) of the histological variables presented by the groups.

\begin{tabular}{|c|c|c|c|c|}
\hline \multirow[t]{2}{*}{ Variables } & \multicolumn{4}{|c|}{ Groups } \\
\hline & A & $\mathrm{B}$ & $\mathrm{C}$ & $\mathrm{D}$ \\
\hline \multicolumn{5}{|l|}{ Acanthosis } \\
\hline light (n) & $80 \%(8)$ & $10 \%(1)$ & $90 \%(9)$ & $50 \%(4)$ \\
\hline mild (n) & $20 \%(2)$ & $80 \%(8)$ & $10 \%(1)$ & $25 \%(2)$ \\
\hline srtong (n) & $0 \%(0)$ & $10 \%(1)$ & $0 \%(0)$ & $25 \%(2)$ \\
\hline total & $100 \%(10)$ & $100 \%(10)$ & $100 \%(10)$ & $100 \%(8)$ \\
\hline \multicolumn{5}{|c|}{ Hyperkeratosis } \\
\hline light (n) & $90 \%(9)$ & $100 \%(10)$ & $10 \%(1)$ & $87.5 \%(7)$ \\
\hline mild (n) & $10 \%(1)$ & $0 \%(0)$ & $10 \%(1)$ & $12.5 \%(1)$ \\
\hline srtong (n) & $0 \%(0)$ & $0 \%(0)$ & $80 \%(8)$ & $0 \%(0)$ \\
\hline total & $100 \%(10)$ & $100 \%(10)$ & $100 \%(10)$ & $100 \%(8)$ \\
\hline \multicolumn{5}{|l|}{ Dysplasia } \\
\hline light (n) & $100 \%(10)$ & $0 \%(0)$ & $10 \%(1)$ & $0 \%(0)$ \\
\hline mild (n) & $0 \%(0)$ & $90 \%(9)$ & $80 \%(8)$ & $62.5 \%(5)$ \\
\hline srtong (n) & $0 \%(0)$ & $10 \%(1)$ & $10 \%(1)$ & $37.5 \%(3)$ \\
\hline total & $100 \%(10)$ & $100 \%(10)$ & $100 \%(10)$ & $100 \%(8)$ \\
\hline \multicolumn{5}{|l|}{ Cell atypia } \\
\hline present (n) & $100 \%(10)$ & $10 \%(1)$ & $0 \%(0)$ & $62.5 \%(5)$ \\
\hline absent (n) & $0 \%(0)$ & $90 \%(9)$ & $100 \%(10)$ & $37.5 \%(3)$ \\
\hline total & $100 \%(10)$ & $100 \%(10)$ & $100 \%(10)$ & $100 \%(8)$ \\
\hline
\end{tabular}




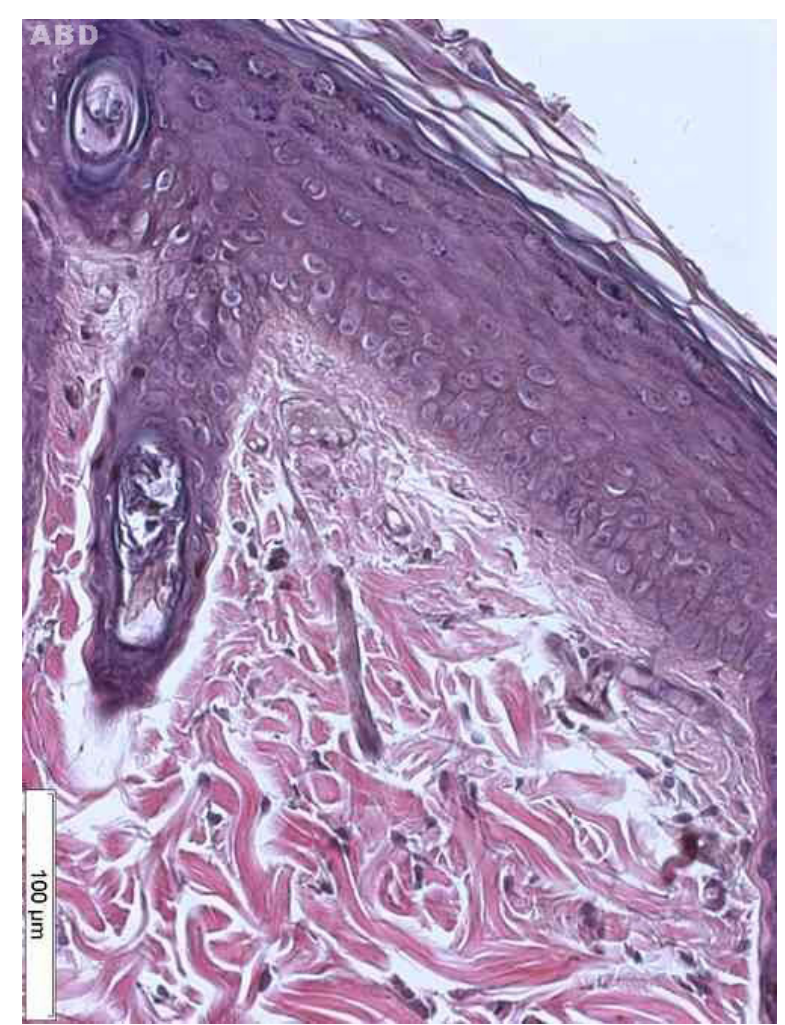

FIGURE 5 - Group A: mild dysplasia, acanthosis and dermic edema.

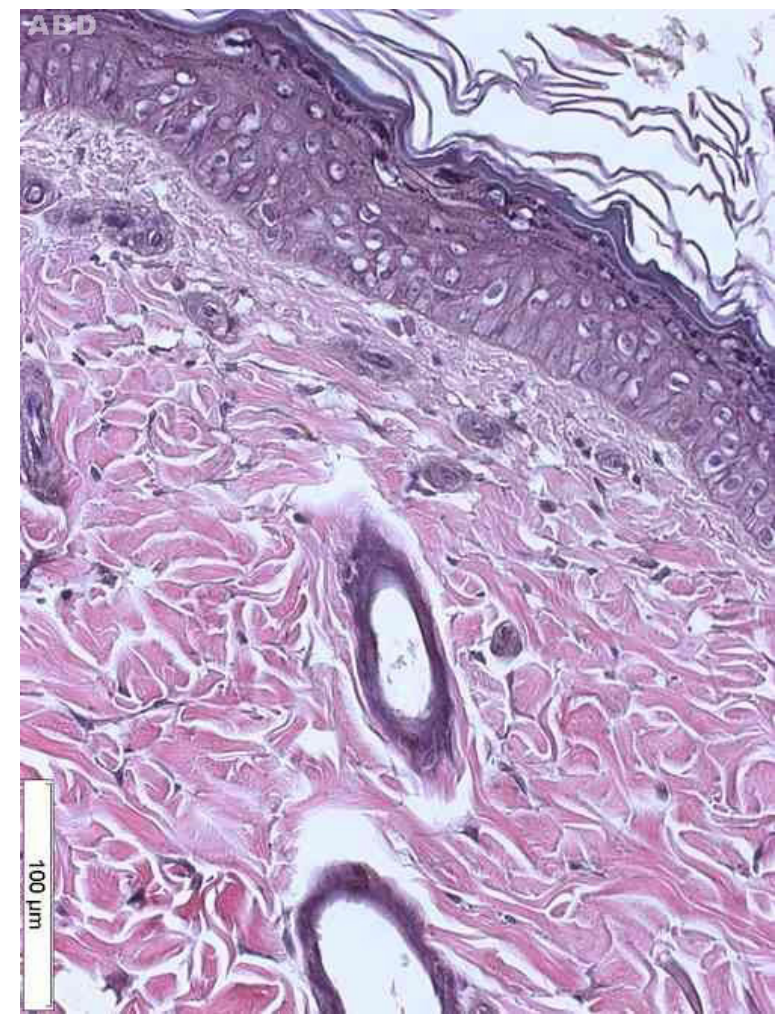

FIGURE 7 - Group C: atipic cells, hyperkeratosis, diskeratosis and dysplasia.

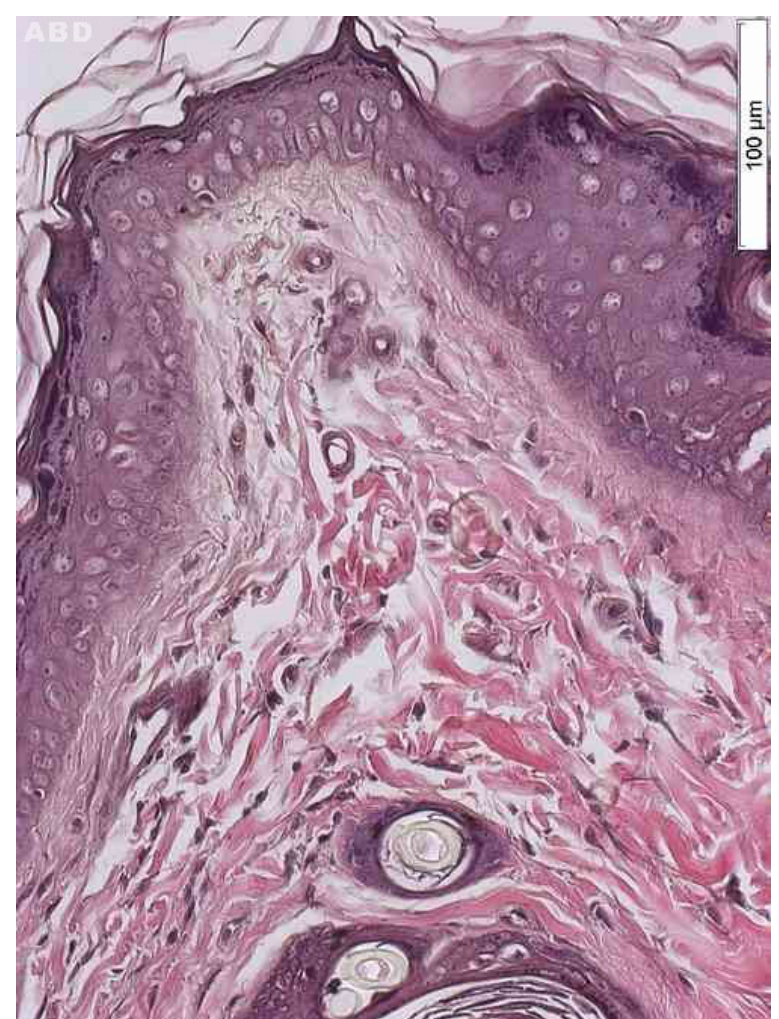

FIGURE 6 - Group B: hyperkeratosis, diskeratosis, atipic cells and dysplasia.

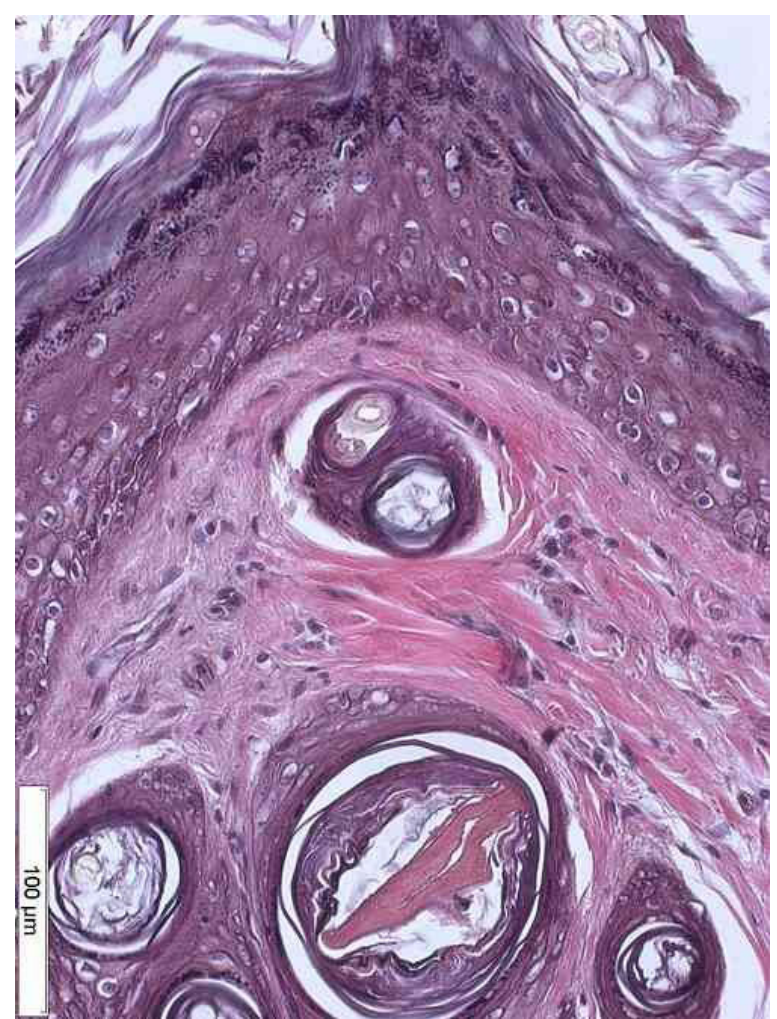

FIGURE 8 - Group D: atipic cells, dysplasia, superior dermic edema and diskeratosis. 


\section{Discussion}

UVR is proved to be carcinogenic, acting directly on the cellular DNA and causing cutaneous immunosuppression, mainly through its UVR-B band, being the main etiological factor of the main $\mathrm{SC}^{1-5,18-20}$. Experimental research using animal models (rats, mice) has shown the association between the exposure to UVR and $\mathrm{SC}^{17,19-23}$. The association between pesticides and cancer has already been well demonstrated dem, $^{8,24,26}$ and some studies cover the association between pesticides and $\mathrm{SC}^{2,24-26}$; however, there are very little studies showing the association between UVR, pesticides and SC in animal models ${ }^{27}$. Clinical and experimental studies have not explained the mechanisms of these alterations yet ${ }^{11,12,27}$.

The cutaneous alterations which occur after chronic solar exposure, such as pigmentation, immunosuppression, keratosis and SC, are related to the wave length and to the total UVR dose that act on the individual susceptibility ${ }^{2,3,5}$.

According to $\mathrm{Honda}^{22}$ and other authors, the chronic exposure to UVR may increase the occurrence of mutations on p53 gene, causing a deregulation in the apoptosis pathway and start SC. According to Matsumara ${ }^{4}$, at the molecular level, UVR damages the DNA to pyridimine dimmers and photoproducts, which are normally repaired through excision repair system, and affirms that photocarcinogenesis involves the buildup of genetic alterations as well as the immune system modulation and finally causes the development of SC.

According to Roewert-Huber et al. ${ }^{27}$, the dermatological elementary lesion caused by the sun rays are initially seen as erythema, then as desquamation and finally as scars forming an actinic keratosis, followed by the formation of a crust and even the evolution to $\mathrm{SCC}^{27}$.

This study shows (time 1), in the group of animals exposed to UVR-B (Group A), a higher prevalence of erythema (Figure 1). As the exposure goes on (times 2 and 3 ), it gets to the following evolution step (erythema + desquamation) (Table 1), which can be considered as the first step in the formation of actinic keratitis (AK). It is likely that this is due to the expected action of UVR-B that happens every time the exposure goes over the tolerance limit. They happen as a consequence of a pericapillar aromatic protein oxidation process. This molecular alteration causes protaglandins liberation and also the release of other vasodilation substances through mastocytes degranulation and through the release of erytrogenic substances as a consequence of the lesion of keratinocytes and leukocytes ${ }^{2,3,5}$. To the development of SCC and BBC, the correlation between the UVR absorption and the start of cutaneous neoplasia are conclusive although questionable in melanoma ${ }^{2-4}$. Honda et $a l .{ }^{22}$ managed to develop SC in mice which were exposed to chronic UVR-B after 14 weeks. Wulff et al. ${ }^{16}$ tested the effect of celecobrix to determine the effects of anti-inflammatory treatment associated to immunosuppression in the development of SC previously initiated and promoted by using mice which were exposed to UVR-B three times a week for 15 weeks to induce the development of SC.

In the groups of animals exposed simultaneously to $\mathrm{UVR}+\mathrm{AGRO}$ (B and C), it is possible to see alterations which start with erythema and progress to keratosis as the histologic study reveals (Figures 2 and 3). Many authors, after the exposure of the mice and rats to UVR, concluded that the cutaneous carcinomas appear depending on the radiation dose. The latency period is additionally influenced by the radiosensibility genetically determined (quantity of melanin in the skin and DNA repair) and by the action of sincarcinogenic and concarcinogenic factors (including pesticides). Wang et al. ${ }^{18}$ induced SC in mice by using UVR-B and UVR-A associated to benzopyrene. Gallagher et $a l .{ }^{25}$ associated plasmatic levels of polichloridebifeniles (organchloride), sun and the risks of CM.

In the group of animals exposed only to the pesticide, the predominant cutaneous alterations were keratosis (Figure 4) with an expressive level of erythema and erythema + desquamation. This evidence is in accordance with information from Oregon State University in its Extonet archives 8 : "a quantity of pesticide absorbed by the SCis sufficient to produce toxic reactions including death, skin irritation and cutaneous eruption or inflammation and its level is a direct result of the level of chemical or physical irritation (dose-response)". Still, according to the archive, the organophosphate in this study is the cause of allergic contact dermatitis, which is clinically seen as erythema, inflammation and in a later stage, skin thickening ${ }^{8}$. The formation of keratosis predominantly in the pesticide group (D) in this study can indicate initial neoplastic lesions (AK).

According to Roewert-Huber et al. ${ }^{27}$, microscopically, in the initial phase of the induced aggression by UV rays, hyperkeratosis and acanthosis happen ${ }^{27}$ (Table 2) and are in accordance with the findings of this study for all groups. The acathosis is determined both by the aggression UVR-induced and by the irritative action of the pesticide . $^{8}$

As for the hyperkeratosis, the expected effected of the UVR action could be observed in groups A and B, the same way as it was found by Popim ${ }^{2}$ and Roewert-Huber et al. ${ }^{27}$, being part of the histologic alterations that suggest the diagnosis for $\mathrm{AK}^{2,3,5,18,27}$. 
For group C, the action of UVR with the pesticide together resulted in the development of the hyperkeratosis more heavily, which possibly means an inducting action to precancerous lesions ${ }^{26}$.

For group D (pesticide) there is an absolute predominance of the light form of hyperkeratosis, which suggests the irritant effect (contact dermatitis) of this substance ${ }^{8}$.

Regarding to dysplasia, we can see that group A showed only mild dysplasia (Figure 5), the expected action of UVR alone ${ }^{19}$. Wang et $a l .{ }^{26}$ found skin tumors in mice irradiated with UV rays associated with benzopyrene for 30 weeks. Further studies using a longer exposure time will be needed to observe the evolution of skin lesions caused by UVR association.

The microscopic findings in this study suggest that the lesions characterize the diagnosis of actinic keratosis, which was more severe in groups which had the association between the pesticide and UVR-B, including a higher level of dysplasia.

Actinic keratosis is considered as cutaneous neoplasia with chromosomal abnormalities, which is consequence of the long solar exposure, but can also be due to the exposure to radiations from artificial sources and aromatic hydrocarbons ${ }^{2}$. Histologically, it is seen mainly as an epidermal thickening associated to various levels of dysplasia, which varies from small alterations to carcinoma in situ. The most frequent type of solar keratosis presents acanthosis and hyperkeratosis ${ }^{27}$. The $\mathrm{AK}$ is different from the SCC due to the absence of inversion of the dermis ${ }^{18,26}$. Epithelial dysplasia is constant and consists of loss of maturation, abnormal cell polarity, nuclear and cytoplasmic pleomorphism, keratinization of individual cells and mitotic figures abnormally located ${ }^{26,27}$.

The cutaneous alterations caused by the ultraviolet radiation have already been demonstrated, as well as the carcinogenic potential of pesticides to the organism as a whole. In the daily dermatological practice, the clinical evaluation must be complemented by the laboratory evaluation. Histological findings in this study characterize the diagnosis of actinic keratosis for UVR, UVR + AGRO and AGRO, more pronounced where there was association between UVR-B and the pesticide, since dysplasia was present in a higher degree.

\section{Conclusions}

Concurrent association of UVR-B to organophosphate pesticide produced more severe lesions microscopically, although this has not been so apparent macroscopically. In daily practice the clinical evaluation should be complemented with laboratory evaluation. Histological evaluation is more reliable than the clinical evaluation to define the type of lesion inducted by UVR either or not associated to pesticides.

\section{References}

1. INCA. Instituto Nacional de Câncer. Ministério da Saúde (Brasil). Estimativa 2010: Incidência de Câncer no Brasil. Rio de Janeiro: INCA; 2009.

2. Popim RC, Corrente JE, Marino JAG, Souza C A. Câncer de pele: uso de medidas preventivas e perfil demográfico de um grupo de risco na cidade de Botucatu. Cienc Saude Coletiva. 2008;13(4):1331-6.

3. Oliveira LMC, Glauss N, Palma A. Hábitos relacionados à exposição solar dos professores de educação física que trabalham com atividades aquáticas. An Bras Dermatol. 2011;86(3):173-8.

4. Matsumura Y, Honnavara NA. Toxic effects of ultraviolet radiation on the skin.Toxicol Appl Pharmacol. 2004;195(3):298-308.

5. Castilho IG, Sousa MAA, Leite RMS. Fotoexposição e fatores de risco para câncer da pele: uma avaliação de hábitos e conhecimentos entre estudantes universitários. An Bras Dermatol. 2010;85(2):173-8.

6. Rodust PM, Stockfleth E, Ulrich C, Leverkus M, Eberle J. Source. UV- induced squamous cell carcinoma-a role for antiapoptoticsignalling pathways. Br J Dermatol. 2009;161 Suppl (3):107-15

7. Mantese SAO, Berbert ALC, Gomides MDA, Rocha A. Carcinoma basocelular - Análise de 300 casos observados em Uberlândia MG. An Bras Dermatol. 2006;81(2):136-42.

8. Extension Toxicology Network. Toxicology Information Briefs Extension Service/National Agricultural Pesticide Impact Assessment Program. Available from http://extoxnet.orst.edu.

9. Bedor CNG, Ramos LO, Pereira PJ, Rêgo MAV, Pavão AC, Augusto LGS. Vulnerabilidades e situações de riscos relacionados ao uso de agrotóxicos na fruticultura irrigada. Rev Bras Epidemiol. 2009;12(1):39-49.

10. IBGE - Instituto Brasileiro de Geografia e Estatística. Produto Interno Bruto dos Municípios 2002-2005. Disponível em http:// www.ibge.gov.br.

11. Fisher SM, Kripke ML. Systemic alteration induced in mice by ultraviol p. light irradiation and its relationship to ultraviolet carcinogenesis. Proc Natl Acad Sci USA. 2003;74:1688-92.

12. Mitchell DL, Volkmer B, Breitbart EW, Byrom M, Lowery MG, Greinert R. Identification of a non-dividing subpopulation of mouse and human epidermal cells exhibiting high levels of persistent ultraviolet photodamage. J Invest Dermatol. 2001;117:590-5.

13. Kligman LH, Gebe M, Alper R, Kefalide, NA. Collagen metabolism in ultraviolet irradiated hairless mouse skin and its correlation to histochemical observations. J Invest Dermatol. 1989;93:210-4.

14. Schwartz E, Cruickshank FA, Perlish JS, Fleischmajer R. Alterations in dermal collagen in ultraviolet irradiated hairless mice. J Invest Dermatol. 1989;93:142-6.

15. Schwartz E. Connective tissue alterations in the skin of ultraviolet irradiated hairless mice. J Invest Dermatol. 1988;91:158-61.

16. Wulff BC, Thomas-Ahner JM, Schick JS, Oberyszyn TM. Celecoxib reduces the effects of acute and chronic UVB exposure in mice treated with therapeutically relevant immunosuppressive drugs. Int J Cancer. 2010;126(1):11-8.

17. Takahama Jr A, Gonzaga Heron FS, Jorge MA, Chaves MD. Ceratoacantoma: revisão da literatura J Bras Med. 2005;88(5):31-4.

18. Wang X, Sistrunk C, Rodriguez-Puebla ML. Unexpected reduction of skin tumorigenesis on expression of cyclin-dependent kinase 6 in mouse epidermis. Am J Pathol. 2011;178(1):345-54.

19. Nandakumar V, Vaid M, Tollefsbol TO, Katiyar SC. Aberrant DNA hypermethylation patterns lead to transcriptional silencing of tumor suppressor genes in UVB-exposed skin and UVB-induced skin tumors of mice. Carcinogenesis. 2011;32(4):597-604. 
20. Bruins W, Zwart E, Attardi LD, Iwakuma T, Hoogervorst EM, Beems RB, Miranda B, van Oostrom CT, van den Berg J, van den Aardweg GJ, Lozano G, van Steeg H, Jacks T, de Vries A. Increased sensitivity to UV radiation in mice with a $\mathrm{p} 53$ point mutation at Ser389. Cell Mol Biol. 2004;24(20):8884-94.

21. González Maglio DH, Paz ML, Ferrari A, Weill FS, Nieto J, Leoni J. Alterations in skin immune response throughout chronic UVB irradiation-skin cancer development and prevention by naproxen. Photochem Photobiol. 2010;86(1):146-52.

22. Honda A, Abe R, Yoshihisa Y, Makino T, Matsunaga K, Nishihira J, Shimizu H, Shimizu T. Deficient deletion of apoptotic cells by macrophage migration inhibitory factor (MIF) overexpression accelerate photocarcinogenesis. Carcinogenesis. 2009;30(9):1597605.

23. Santos SS, Silva IF, Koifman RJ. Exposição a substâncias químicas e câncer: aspectos epidemiológicos, genéticos e moleculares. Cad Saúde Coletiva Rio de Janeiro. 2008;16(4):613-58.

24. Rodwall Y, Dich J, Wiklund K. Cancer risk in offspring of male pesticide applicators in agriculture in Sweden. Occup Environ Med. 2003;60:798-801.

25. Gallagher RP, Macarthur AC, Lee TK, Weber JP, Leblanc A, Mark Elwood J, Borugian M, Abanto Z, Spinelli JJ. Plasma levels of polychlorinated biphenyls and risk of cutaneous malignant melanoma: a preliminary study. Int J Cancer. 2011;128(8):1872-80.

26. Wang Y, Zhou X, Weinstein E, Maryles B, Zhang Y, Moore J, Gao D, Atencio DP, Rosenstein BS, Lebwohl M, Chen HD, Xiao T, Wei H. p53 gene mutations in SKH-1 mouse tumors differentially induced by UVB and combined subcarcinogenic benzo[a]pyrene and UVA . Photochem Photobiol. 2008;84(2):444-9.

27. Roewert-Huber J, Stockfleth E, Kerl H. Pathology and pathobiology of actinic keratosis - an update. Br J Dermatol. 2007; 157 Suppl 2:18-20.

\section{Correspondence:}

Tania Rita Moreno de Oliveira Fernandes

Disciplina de Técnica Operatória e Cirurgia Experimental

Rua Botucatu, 740

04023-900 São Paulo - SP Brasil

trmofernandes@gmail.com

Received: Sept 17, 2013

Review: Nov 18, 2013

Accepted: Dec 20, 2013

Conflict of interest: none

Financial source: none

${ }^{1}$ Research performed at Laboratory of Experimental Surgery, Sao Francisco Valley University (UNIVASF), Petrolina-PE, Brazil. Part of Master degree thesis, Postgraduate Program in Interdisciplinary Surgical Science, Sao Paulo Federal University. Tutor: Helio Plapler. 